\title{
A study of integrated cattle-rice farming in rainfed fields in Jambi, Indonesia
}

\author{
Bustami*, and Sari Yanti Hayanti \\ Jambi Assessment Institute for Agricultural Technology, J1. Samarinda Paal V No. 11 Kota Jambi, \\ Jambi, Indonesia
}

\begin{abstract}
The objective was to obtain information about the impact of innovation in rice cattle integration on farmers' income in Sarolangun District, Jambi by using technology IPM Paddy. A study was carried out on the utilisation of cattle waste for rice farming in rainfed rice fields in Pematang Kabau at Sarolangun District, Jambi, Indonesia, from October 2017 to February 2018. There were 25 cooperators in the Sumber Rezki farmer group divided into three treatment groups. The first group applied manure and inorganic treatment for rice cultivation and cattle maintenance with the intensive system, the second group applied inorganic treatment for rice cultivation and cattle maintenance with intensive system, and the third cooperator farmers applied no manure and inorganic treatment and cattle maintenance with extensive system. The rice variety namely Inpara 3 and Bali cattle were used in the experiment. Data was analyzed descriptively. The results showed the production of harvested dry unhulled rice in each treatment was 6.56, 4.75 and 3.51 tons/ha, and birth rate of calves was 84.6, 80 , and $75 \%$ each treatment, respectively. The revenue farming analysis was Rp. 20,552,000, -, Rp. 18,606,250, - and Rp. 14,509,300, - and the RC ratio was $2.03,1.85$ and 1.64 , respectively.
\end{abstract}

\section{Introduction}

The rice-livestock integration system is an effort to increase farmers' income through increased rice production, which is integrated synergistically with cattle raising. Regulation of Indonesia's Ministry of Agriculture Number 50 / permentan / OT.140 /8/2012 stated the guidelines for developing agricultural areas. The aims of regulation are to support the achievement of the four success targets [1], namely: 1). Achieving sustainable selfsufficiency, 2). Increasing food diversification, 3). Increasing added value, competitiveness and export, and 4). Increasing farmer's welfare.

An integrated agricultural development system that involves rice plants and technology innovation can be considered one way to implement the advancement of farm area and increase the farmers' income. The pattern of integration is to use rice straw for cattle feed and cattle excrement for plant fertilizer. The technology package introduced was: recommended rice cultivation, cattle fattening, processing of livestock manure for organic fertilizers. Farmers are divided into two groups, namely 20 farmers participating in the

* Corresponding author: bustami130@gmail.com 
integration pattern and 10 traditional farmers. Basuni [2] reported that the increase in production by applying manure as much as 2 tons/ha could increase rice production by $16 \%$ compared to the traditional farming method. Furthermore, [3] stated, an integrated agricultural system is a system that combines various plant and animal species. He also noted that the application of multiple techniques and the combination could create suitable conditions to protect the environment and helps farmers maintain land productivity to increase their income by diversifying farming.

The Agricultural Research and Development Agency has produced technological innovations for Plant-Livestock Integration System in agricultural business systems for various agroecosystems. It has been proven to increase farming efficiency as livestock plays a significant role in supplying meat, labor, fertilizer biogas, and waste utilization. Another thing to consider is that a superior technology that can be beneficial for the profit of the beef cattle development business is needed [4]. Furthermore, [5] reported the integration system is the application of an integrated company through a common external input approach between food crop commodities (rice, corn, cassava and soybeans), plantation commodities (sugarcane, palm oil and cocoa) and livestock. The by-products of these plants can be used as feed, and the excrement of animals (cows or cattle) can be utilized as the main ingredient for composting. [6] stated that the main principle of implementing the Integrated Plant Management (IPM) concept formulated by the Ministry of Agriculture through the Agricultural Research and Development Agency is participatory, specification of the location, synergic, harmonious and dynamic (Table 1).

Table 1. Guidelines for the technology component of the IPM Paddy

\begin{tabular}{|c|c|c|}
\hline Management process & Technology components & $\begin{array}{l}\text { Check the } \\
\text { adoption }\end{array}$ \\
\hline Planning before planting & $\begin{array}{l}\text { 1. New Superior Varieties. } \\
\text { 2. Labelled Seed } \\
\text { 3. Soil management according to } \\
\text { season and cropping patterns }\end{array}$ & $\begin{array}{l}\mathrm{V} \\
\mathrm{V} \\
\mathrm{V}\end{array}$ \\
\hline Planting method & $\begin{array}{l}\text { 4. Utilisation of young plant seed } \\
\text { 5. Planting seeds for 1-3 } \\
\text { stems/clumps } \\
\text { 6. Jajar legowo (Jarwo) planting } \\
\text { method } \\
\text { 7. Weeding } \\
\end{array}$ & $\begin{array}{l}\mathrm{v} \\
\mathrm{v} \\
\mathrm{v} \\
\mathrm{v}\end{array}$ \\
\hline Nutrient management & $\begin{array}{l}\text { 8. Fertilisation based on plant needs } \\
\text { 9. Organic matter application }\end{array}$ & $\mathrm{v}$ \\
\hline Water management & 10. Intermittent irrigation & $\mathrm{x}$ \\
\hline Pest and Disease Management & 11. Control of pest organism & $\mathrm{v}$ \\
\hline Harvest Management & $\begin{array}{l}\text { 12. Ontime harvest and early grain } \\
\text { threshing }\end{array}$ & $\mathrm{v}$ \\
\hline
\end{tabular}

Remark: $\mathrm{v}=$ Yes, $\mathrm{x}:$ No

However, information on the impact of the integration of rice plants with cattle in Sarolangun Jambi Regency was not yet available. The purpose of this study was to obtain information about the impact of innovation in rice cattle integration on farmers' income in Sarolangun District, Jambi by using technology IPM Paddy, using the variety of Inpara 3. The description of the paddy variety is mentioned in Table 2 . 
Table 2. Description of rice varieties Inpara 3

Source:[7]

\begin{tabular}{|l|c|}
\hline \multicolumn{1}{|c|}{ Parameter } & Description \\
\hline Plant Age & 127 days \\
Plant Form & Upright \\
Height & $108 \mathrm{~cm}$ \\
Leaf & Upright \\
Grain Form & average \\
Grain Color & Yellow \\
Grain Threshing & average \\
Lodging & average \\
Rice Texture & Pera \\
Average yield & 4.6 ton/ha \\
Potential yield & $5.6 \mathrm{t} /$ ha of \\
Plant Prompts & Lowland swamps, tidal and irrigated \\
& fields prone to flooding. \\
\hline
\end{tabular}

\section{Methodology}

\subsection{Time and location}

A study was carried out on cattle-rice farming in the Pematang Kabau Village Air Hitam Region Sarolangun District, Jambi Province, Indonesia from March 2017 to February 2018. The study was adjusted to the planting season during the rainy season.

\subsection{Respondents}

The study was conducted in the Rezki Pematang Kabau farmer group, Air Hitam sub-district, Sarolangun, Jambi, Indonesia with 25 farmers. The selection process for the location was established deliberately as the farmer group received cattle as input provision, which required assistance and monitoring to manage 47 Bali cattle and rice plant cultivation.

\subsection{Data collection}

Parameters in this study were type of technology, paddy variety (Inpara 3), land area/cooperator, dose of manure, activity time (month), total cooperator, production of grain on harvest, type of rice field, paddy planting index (IP), amount of cattle before assessment, the number of calves born, percentage of calving, total of pregnant cows, percentage of pregnant, and price of harvested dry grain (GKP). The percentage of pregnancy is the number of pregnant broods from the total existing brood. The number of calves is the total number of calves born to the total number of pregnant cattle. Percentage of births is the number of calves from all pregnant cattle.

The observation method was carried out by dividing the cooperative farmers based on the integrated rice cattle system and the livestock cultivation system with three treatment groups; two group with 10 repetitions (treatment I and II) and 5 repetitions (Treatment III), namely:

Treatment I: 10 farmer cooperators implemented IPM rice and apply manure to paddy fields at a dose of 2 tons/ha, with the maintenance of cattle was intensive system. Treatment II: 10 lowland rice farmers who do not apply manure to the paddy fields with IPM rice, because manure are used for oil palm plantations, with the maintenance of cattle is intensive system. Treatment III: 5 farmer cooperators who do not apply IPM rice with maintenance of the cattle is extensive system. The data obtained cow-rice farming performance during the 
assessment were analyzed by descriptive method and the data obtained the benefits were analyzed with farming analysis ( $\mathrm{RC}$ ratio).

$$
R C \text { Ratio }=\text { Total capital }(A): \text { Amount of revenue }(B)
$$

Where: $\mathrm{RC}>1$ : decent farming

$\mathrm{RC}=1:$ impasse

$\mathrm{RC}<1:$ not feasible

\section{Results and discussion}

Based on the observations and interviews with 25 farmers in each treatment, the rice farming activity carried out only utilized rainfed rice fields within an area of $5-10$ ha per assigned location, not a stretch of rice fields in general. Thus, further problems have been encountered, such as the appearance of rats and birds. Moreover, all farmers stated that the initial motivation for the farming activities was to fulfil consumption needs. Furthermore, the study results on the cattle-rice farming system can be seen in Table 3 as it depicts the treatment result on the production of rice and the development of cattle reproduction. The table shows that the rice production did show a much difference in each treatment but not with the cattle reproductive development. Implementation of assessment activities is shown in Figure 1.

The rice farming activities were carried out once a year according to the potential of the rainfed rice fields so that the Planting Index (IP) can reach 100\%. According to the advice of field extension officers, the technology used in the study was Integrated Plant Management (IPM). The government provided the inputs and seeds while the dosage of manure was following the treatment. Cooperators carried out the cattle farming activities with an intensive and semi-intensive maintenance system in which the cattle were being shed and tied to move. While being in the cage, the cattle were provided with grass from around the area. The type of cattle used in the study was Balinese cattle, which the government provided. One of the primary and vital factors in raising livestock is the availability of efficient feed. In the assessment location of this study, the source of feed is sufficiently available throughout the year, both natural grass and rice straw. Several types of plants have been identified to naturally grow around the area, as shown in Table 4.

Table 3. Cow-rice farming performance during the assessment

\begin{tabular}{|c|l|c|c|c|}
\hline No & \multicolumn{1}{|c|}{ Description } & $\begin{array}{c}\text { Treatmen } \\
\mathbf{t ~ I ~ ( N = 1 0 ) ~}\end{array}$ & $\begin{array}{c}\text { Treatment II } \\
(\mathbf{N}=\mathbf{1 0})\end{array}$ & $\begin{array}{c}\text { Treatment III } \\
(\mathbf{N}=\mathbf{5})\end{array}$ \\
\hline 1 & Type of Technology & IPM & IPM & - \\
2 & Variety & Inpara 3 & Inpara 3 & Inpara 3 \\
3 & Land area/cooperator (ha) & 0.25 & 0.25 & 0.1 \\
4 & Dose of manure (ton / ha) & 12 & - & No fertilisation \\
5 & Activity time (month) & 10 & 12 & 12 \\
6 & Total cooperator & 6.56 & 4.75 & 5 \\
7 & Production of gry grain on Harvest t / ha & Rainfed & Rainfed & 3.51 \\
8 & Type of rice field & 100 & 100 & Rainfed \\
9 & Paddy Planting Index (IP) & 18 & 19 & 100 \\
10 & Amount of cattle before assesment & 13 & 15 & 8 \\
11 & Total of Pregnant Cows (heads) & 72 & 78 & 80 \\
12 & Percentage of Pregnants (\%) & 11 & 12 & 6 \\
11 & The number of calves born (heads) & 84,6 & 80 & 75 \\
12 & Percentage of calving (\%) & $800-1000$ & $800-1000$ & immeasurable \\
13 & Production of Manure (kg)/cattle & 4,300 & 4,300 & 4,300 \\
14 & Price of Harvested Dry Grain (GKP) & & & \\
& IDR / kg & \multicolumn{2}{|c}{} \\
\hline
\end{tabular}



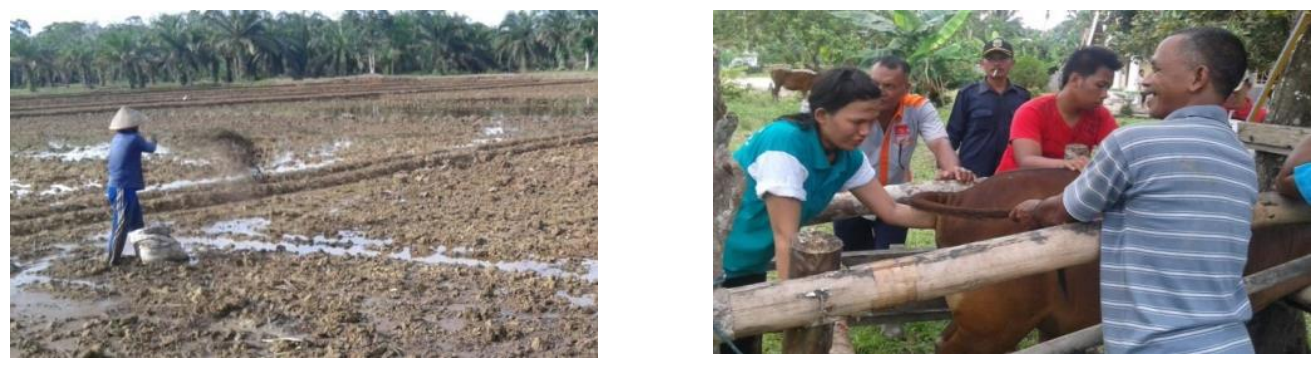

Fig. 1. Implementation of assessment activities

Table 4. Types of natural food available at the study site

\begin{tabular}{|c|l|c|c|}
\hline No & Local resources & Latin name & Growing location \\
\hline 1 & Straw/rice bran & Oryza Sativa & Rice field \\
2 & Reeds & Imperata cylindrica & Empty land \\
3 & Carpet grass & Axanopus compresus & Empty land \\
4 & Legumes & Lablab purpureus & Riverbanks and empty land \\
5 & Kumpai grass & Hymenachne acutigluma & Swamp \\
6 & Kolonjono grass & Brachiaria mutica & Riverbanks \\
7 & Lamtoro & Leucaena leucephala & Hedgerow \\
\hline
\end{tabular}

According Ismeth [8], to increase rice production and farmers' income, a breakthrough program that leads to business efficiency by utilizing local resources is needed. One of which is the integrated system of livestock (cattle)-rice which is expected to overcome nutrient scarcity in rice fields by using organic fertilizers.

Introduce Integrated Plant Management (IPM) technology and optimizing manure application based on Tables 3 and Table 5 to boost rice output and farmers' revenue. Bustami [9] reported implementing Integrated Plant Management (IPM) with 2 tons/ha of manure to rice farming for Inpari 12 rice variety in the Bungo District, Jambi can increase the production from 4.24 to 6.72 tonnes/ha. In addition, farmers who run rice farming businesses use solid organic fertilizers as an effort to cultivate environmentally friendly rice [10]. In rainfed land, solid organic fertilizer is an important component [11] including reducing the use of chemical fertilizers [12]. Organic fertilizers can increase the number of bacteria needed by the soil for plant growth and production [13].

Sukria [14] stated that rice waste, namely bran and straw, has enormous potential for the supply of ruminant feed ingredients because it does not compete with human consumption needs. The rice waste produced can be used as a source of feed supply when forage is difficult to obtain [15]. Rice waste, especially straw, can also be combined with other types of feed to obtain a more economical feed formula for raising cattle. The use of straw was introduced to rice farmers so that straw waste could be converted as a source of feed and not burned [16].

In raising cattle, the addition of one calf for 1 period of maintenance or 12 months is still an ideal livestock business [17]. In raising cattle integrated with rice, increasing the number of livestock is an additional advantage for farmers. In this study, there was an increase in the population in all treatment groups and the highest increase in the number of additions was in the treatment group I as much as $84.6 \%$ (Table 5). 
Table 5. Analysis of cattle-rice farming

\begin{tabular}{|c|c|c|c|c|}
\hline No & Parameter & $\begin{array}{l}\text { Treatment } \\
\text { I }\end{array}$ & $\begin{array}{c}\text { Treatment } \\
\text { II }\end{array}$ & $\begin{array}{l}\text { Treatment } \\
\text { III }\end{array}$ \\
\hline 1 & $\begin{array}{l}\text { Production of GKP (tonnes/ha) } \\
\text { Percentage of calving }(\%)\end{array}$ & $\begin{array}{l}6.56 \\
84.6\end{array}$ & $\begin{array}{c}4.75 \\
80\end{array}$ & $\begin{array}{c}3.51 \\
75\end{array}$ \\
\hline 2 & $\begin{array}{l}\text { Cost / Input (Rp) } \\
\text { Land Management } \\
\text { Cultivation } \\
\text { Weeding } \\
\text { Seed } \\
\text { Fertilizer } \\
\text { Manure } \\
\text { Agrochemical input } \\
\text { Cage } \\
\text { Price per cow/cattle } \\
\text { Total capital (A) }\end{array}$ & $\begin{array}{r}300,000 \\
300,000 \\
50,000 \\
40,000 \\
315,000 \\
100,000 \\
350,000 \\
500,000 \\
8,000,000 \\
10.155 .000\end{array}$ & $\begin{array}{r}300,000 \\
300,000 \\
250,000 \\
40,000 \\
315,000 \\
0 \\
350,000 \\
500,000 \\
8,000,000 \\
10,055,000\end{array}$ & $\begin{array}{r}120,000 \\
120,000 \\
0 \\
20,000 \\
0 \\
0 \\
100,000 \\
500,000 \\
8,000,000 \\
8,860,000\end{array}$ \\
\hline 3 & $\begin{array}{l}\text { Income / output (Rp) } \\
\text { Selling GKP } \\
\text { Selling value of livestock } \\
\text { Selling valu of manure } \\
\text { Amount of revenue (B) }\end{array}$ & $\begin{array}{r}7,052,000 \\
13,000,000 \\
500,000 \\
20,552,000\end{array}$ & $\begin{array}{r}5,106,250 \\
13,000,000 \\
500,000 \\
18,606,250\end{array}$ & $\begin{array}{r}1,509,300 \\
13,000,000 \\
0 \\
14,509,300\end{array}$ \\
\hline 4 & Profit $(\mathrm{Rp})(\mathrm{B}-\mathrm{A})$ & $10,397,000$ & $8,551,250$ & $5,649,300$ \\
\hline 5 & RC Ratio & 2.02 & 1.85 & 1.64 \\
\hline
\end{tabular}

\section{Conclusion}

The study's findings reveal that IPM technology has a positive influence on rice farmers' revenue, which is backed up by an $84.6 \%$ rise in animal population. IPM technology may be used in another agricultural area in Jambi Province, with rice and livestock as the main commodities.

\section{References}

1. Agriculture Ministry. Agricultural area development guidelines. Agriculture Ministry Regulation Number 50/Permentan/OT.140/8/2012 (2012)

2. R. Basuni, Muladno, C. Kusuma, Suryahdi, Food crops science. Agency for Agricultural Research and Development (2010)

3. Mukhlis, M. Noer, Nofialdi, Mahdi. Rice and cattle integrated farming system (2016). [Online]. Available :https://www.researchgate.net/publication/324174642

4. K. Uka, Developmentof Agriculture Innovation 3, 189-205 (2008)

5. A. Priyanti, Accelerated development of laboratory and field school-based croplivestock integration system models: cattle-palm. Acceleration of beef cattle development through livestock crop integration system. IPB Press. Bogor-Indonesia (2017)

6. Suyamto, Z. Zaini, S. Abdurrahman, N. Widiarta, P. Wardana, D.S. Rini, S. Kartaatmaja, M. Yamin, General Guidelines for PTT Paddy Sawah. Badan Penelitian dan Pengembangan Pertanian. Agricultural Departement (2009)

7. A. Jamil, Satoto, P. Sasmita, Y. Baliadi, A. Guswara, Suharna, Description of new superior varieties of rice. Irrigated lowland rice inbreds (Inpari), Inpago upland rice inbreds, swamp rice inbreds (inpara) and rice hybrids (Hipa). Badan Penelitian dan Pengembangan Pertanian. Kementerian Pertanian (2015) 
8. I. Ismeth, Leading animal husbandry and veterinary technology innovation. Pusat Penelitian dan Pengembangan Peternakan. Badan Penelitian dan Pengembangan pertanian. Departemen Pertanian (2006)

9. Bustami, Adri, E. Salvia. Introduction and analysis of new superior varieties (VUB) of rice INPARI 12 in Tanah Sepenggal, Bungo Jambi Regency. Proceedings of the 33rd World Food Day National Seminar. Optimizing local resources through food diversification and improving nutrition. The community welcomes the 2015 ASEAN Economic Community. Pusat Sosial Ekonomi dan Kebijakan Pertanian. Badan Penelitian dan pengembangan Pertanian. Kementerian Pertanian (2014)

10. A. Wihardjaka, E.S. Harsanti, Food 30, 1: 53-64 (2021)

11. A. Kasno, D. Setyorini, I.W. Suastika, Journal of Land Resources 14(1), 15-24 (2020)

12. Gusmiatun, N. Marlina, Journal of Fisheries Agribusiness 11, 2: 91-99 (2018)

13. S. Wahyuni, S. Rianto, U. Muanisah, P. Setyanto, Utilization of organic fertilizer to increase bacterial population and production of gogorancah rice plants. Proceeding Biology Education Conference, 13 (1), 2: $752-756$ (2016)

14. H.A Sukria, R. Krisnan, Source and availability of feed raw materials in Indonesia. Source and availability. Quality standards and formulations. Resource management and feed processing techniques for ruminants. IPB Press. Bogor (2009)

15. Y Yusriani, Elviwirda, M. Sabri, Indonesian Animal Husbandry Journal 17, 2: 163-169 (2015)

16. B. Agustono, M. Lamid, M. Anwar, M.T.E. Purnama, Journal Medik Veterinary, 1, 1: 12-22 (2017)

17. A. Pohontu, A. Lomboan, J.F. Paath, S.C. Rimbing, Jurnal Zootek 38, 1: 102, 113(2018) 